\title{
亜硫酸カルシウム水和物の生成に与えるリン酸 イオンの影響および球晶の多層構造
}

\author{
松 野 昂 士**小石 真 純**
}

要

旨

水酸化カルシウム懸濁液と二酸化硫黄との半回分式不均一反応系 $\left(<40^{\circ} \mathrm{C}\right)$ に三リン酸ナトリウム，ピロリン 酸ナトリウム，要るいはリン酸水素二ナトリウムを少量共存させることにより，亚硫酸カルシウム半水和物球晶 が高収率で得られた。反応温度および上記添加物濃度を変えることにより, 上記反応系から画硫酸カルシウム四 水和物結晶が得られた。添加物の効果の大きさの順は三リン酸ナトリウム>ピロリン酸ナトリウム>リン酸水素 二ナトリウムであった。

上記リン酸塩を加兄て, 半回分式均一系反応を繰り返し行らことにより, 多層構造を有する半水和物球晶が得 られた。また, 上記リン酸塩の添加により, 連続式不均一系反応によっても, 高密度の放射状構造を有する半水 和物球晶がきわめて収率よく生成した。

\section{1. 緒言}

粉体系が有する性質の基礎となるのは，その構成単位 である粒子の大きさ（粒度分布，平均粒径）と形態であ ることが知られている11。粉体とプラスチックなどから なる複合材料に打いても, その物理的強度を粒子の大き さ，形態が支配することはよく知られている2)。このた め, 粒子サイズ拈よび粒子形態に関して多くの研究が行 われている。あらゆる形の中でもっとも単純であり, そ れ自身の物理的強度が大きく, また粉体の流動性が高い 球形粒子に関しても, その調製法, 粉体物性について多 くの報告がある。球形シリカ ${ }^{3)}$, 球形石こ ${ }^{4)}$ 虰よび球 形マグネタイト5などに関するものが例としてあげられ る。球形シリカは無定形シリカからなっていると, 球形 石こうはウィスカーが不規則にからみ合った結果生成し たものであると，また，球形マグネタイトはマグネタイ トの微小な一次粒子が凝集し, これらが, 接触再結晶機 構 (contact-recrystallization mechanism) ${ }^{6}$ によって大

昭和 58.4 .22 受理

* 北里大学医学部 神奈川県相模原市北里 1-15-1（广228）

** 東京理科大学薬学部 東京都新宿区市ヶ谷船河原町 12 (T162)
きくなり，さらに，これらの表面へのマグネタイト一次 粒子の付着が起こり生成したものであるとされている。

これらとは別に，多くの結晶核ができた中心から放射 状に多数の板状，柱状，あるいは針状の結晶が 成長し て，全体として球形をとっている結晶（球晶）が存在す る7。有機高分子化合物，たと光ばナイロンやポリエチ レンなどでは球晶はごく普通に見られる結晶の一形態で ある8,9)。末た，造岩鉱物中に存在する無機化合物の球晶 についても比較的報告が多く，よく知られている ${ }^{10,11}$ 。 しかし，人為的に合成される無機化合物については，そ の球晶生成に関する報告がきわめて少ない(12,13)。

著者らは, 先に水酸化カルシウムと二酸化硫黄との半 回分式不均一反応系に銅（II）イオンなどの金属イオン を適量共存させると, 反応生成物である亜硫酸カルシウ ム半水和物の大部分が球晶（CSH-sp）として生成する ことを明らかにした ${ }^{14)}$ 。本研究では, 同じ水酸化カルシ ウムと二酸化硫黄との半回分式不均一反応系に三リン酸 ナトリウム (STPP), ピロリン酸ナトリウム (SPRP), あるいはりン酸水素二ナトリウム (DSHP) を少量加克 ることにより，生成物の大部分が CSH-sp として得ら れること，拉よび球晶を構成する結晶の配向性などを明 らかにした。また半回分式不均一系反応 (以下, 半回分 式反応とする）を繰り返すことにより，多層構造を有す 
る CSH-sp が生成することを明らかにした。この多層構 造を有する CSH-sp は，その中心あるいは層間に他の 物質，たとえば染料，顔料などを含有させ，複合化する ことにより，耐熱性にすぐれた複合染料および複合顔料 になるとも考えられ，新しい複合材料の基礎になる可能 性があるものとして興味深い。さらに，水酸化カルシウ ムと二酸化硫黄との連続式不均一反応系に前述のリン酸 イオンのいずれかを少量共存させた場合にも，きわめて 収率よく CSH-sp が生成することを明らかにしたので 報告する。

\section{2. 実験}

\section{1 試 薬}

水酸化カルシウム预よび二酸化硫黄は既報 ${ }^{14)}$ に述べた 市販品をそのまま用いた。STPP（無水和物）は 1 級品, SPRP (十水和物) および DSHP (十二水和物) は特級 品をそのまま用いた。供試料の STPP, SPRP および DSHP はいずれも和光純薬製である。

\section{2 装置}

半回分式反応は既報 ${ }^{14)}$ に述べたガラス製（1 l l) の反応 器を用いて行った。連続式不均一系反応 (以下, 連続式 反応とする）は図-8に示した反応器を用いて行った。連 結されている左右の反応器 $(\mathrm{R}-1, \mathrm{R}-2)$ はガラス製であ り, いずれも $1 l$ の容量 $(87 \mathrm{~mm} \phi \times 205 \mathrm{mmH})$ を有して いる。連続式反応の場合もガス分散と液のかきまぜは, 半回分式反応の場合と同様に羽根付きタービン型かきま ぜ機 $(50 \mathrm{~mm} \phi$, SUS 32 製, 周速 $2.62 \mathrm{~m} / \mathrm{s})$ を用いて行 った。 R-1 から R-2 への反応液の移動掞よび R-2 から の反応液の抜き出しは，オーバーフロー方式によった。

\section{3 ソルの調製}

水酸化カルシウム懸濁液は市販の微粉末状水酸化カル シウムの所定量をイオン交換水（比抵抗 $>5 \times 10^{6} \Omega \cdot \mathrm{cm}$ ) に加光, かくはんしながら瞹濁液 $1 l$ 当たり, $500 \mathrm{ml}$ $\min$ の速度で窒素を 1 時間吹き込又調製した。STPP, SPRP，DSHP はそれぞれ所定量を $30 \mathrm{ml}$ のイオン交換 水に溶解したのち, 水酸化カルシウム 懸濁液に添加し た。反応は水酸化カルシウム懸濁液濃度 $0.4 \mathrm{M}$, 二酸化 硫黄濃度 $50 \mathrm{vol} \%\left(\mathrm{~N}_{2}\right.$ 希釈)で行った。半回分式反応は 反応器内の水酸化カルシウム懸濁液 $(1 l)$ に $1.6 \times 10^{-2}$ $\mathrm{mol} / \mathrm{min}$ の速度で二酸化硫黄を 供給して行い, $\mathrm{pH}$ が 7.0 まで低下したときに供給を止め，反応を停止した。

連続式反応は $\mathrm{R}-1$ および $\mathrm{R}-2$ の反応液（各 $1 l$ ) の $\mathrm{pH}$ をそれぞれ 7.0〜8.0 に保ちながら行った。 $\mathrm{R}-1$ 打 よび R-2 には，水酸化カルシウム懸濁液 (0.4 M) を $40 \mathrm{ml} / \mathrm{min}\left(1.6 \times 10^{-2} \mathrm{molCa}(\mathrm{OH})_{2} / \mathrm{min}\right)$ の速度で, 二
酸化硫黄 $(50 \mathrm{vol} \%)$ を $1.6 \times 10^{-2} \mathrm{molSO}_{2} / \mathrm{min}$ の速度で 供給して連続式反応を行った。 R-1 および R-2 の反応 液の $\mathrm{pH}$ の調整は二酸化硫黄の 供給量を増減して行っ た。

\section{4 組成分析}

$\mathrm{CaO}$ はDTA 溶液で滴定し, $\mathrm{SO}_{2}$ はヨウ素滴定法 で, $\mathrm{CaSO}_{4}$ は JIS-K 0102-1971 の比濁法に準拠した方 法で, $\mathrm{Ca}(\mathrm{OH})_{2}$ は塩酸溶液による中和滴定法で求めた。

\section{5 電子顕微鏡}

日立電界放射型走査電子顕微鏡 S-700を使用した。 厚さ約 $100 \AA$ の金蒸着膜で試料を被覆し, 加速電圧 20 $\mathrm{kV}$ で観察した。

\section{6 微量元素分析}

HITACHI H-500 型電子顕微鏡に装着された KEVEX $5100 \mathrm{C} \mathrm{X}$-ray energy spectrometer を用いて行った。

\section{$2.7 \mathrm{X}$ 線分析}

回転試料台付き島津自記 X線回折装置 XD-3 を用い て行った。

\section{3. 結果および考察}

\section{1 CSH-sp の生成に与える各種リン酸イオンの影} 響

添加物濃度と CSH-sp の生成割合 (FRcsh-sp) 拉よ び亜硫酸カルシウム四水和物の生成割合（FRcst）との 関係を図-1 に示す。FRcsh-sp および FRcst は前報 ${ }^{14)}$ と同じ方法で求めた。反応は回分式不均一系で, 温度 $5^{\circ} \mathrm{C}$ で行った。その他の反応条件は 2.3 に記した通りで

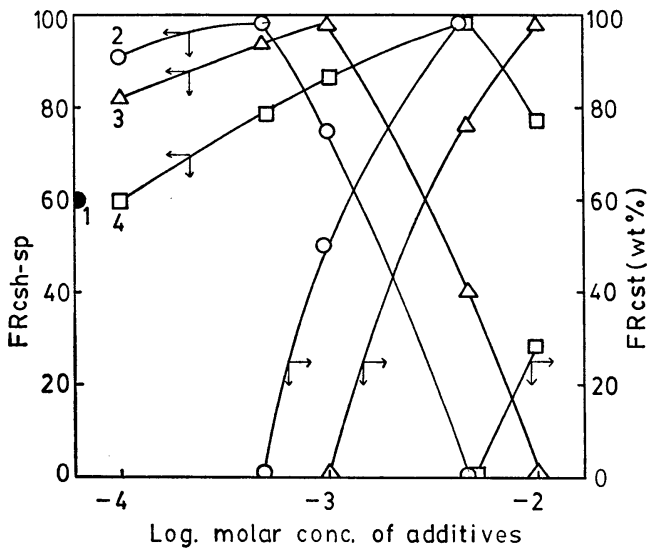

Fig. 1. The changes of the CSH-sp formation ratio (FRcsh-sp) and the CST formation ratio (FRcst) as a function of the concentration of additives

Reaction temperature : $5^{\circ} \mathrm{C}$

$1:$ Nonadditive $2: \mathrm{STPP} \quad 3: \mathrm{SPRP} \quad 4: \mathrm{DSHP}$ 


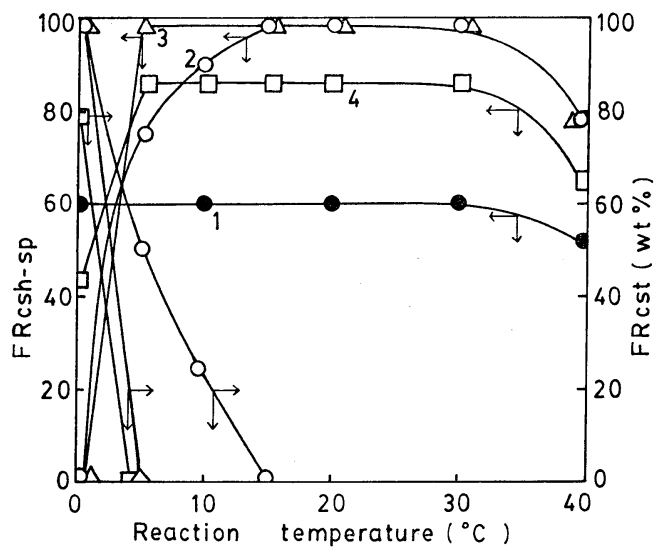

Fig. 2. The changes of the FRcsh-sp and FRcst as a function of the reaction temperature The concentration of additives : $1.0 \times 10^{-3} \mathrm{M}$ $1:$ Nonadditive $2: \mathrm{STPP} \quad 3: \mathrm{SPRP} \quad 4: \mathrm{DSHP}$

ある。添加物濃度と FRcsh-sp の関係を表わす 3 本の曲 線には，それぞれ極大点が存在する。この極大点に対応 する濃度より添加物濃度が小さい場合には, 亜硫酸カル シウム半水和物の 無定形結晶集合体が 生成するために FRcsh-sp が減少し, 極大点より高濃度側では CST が 生成するために FRcsh-sp が減少する。STPP, SPRP および DSHP のいずれの場合も，FRcsh-sp の極大值 は98であるが，その值を示す濃度は異なっており， STPP が $5.0 \times 10^{-4} \mathrm{M}$, SPRP が $1.0 \times 10^{-3} \mathrm{M}$, DSHP が $5.0 \times 10^{-3} \mathrm{M}$ である。

FRcst の值は添加物濃度の増加に伴って増大し, STPP の場合 $5.0 \times 10^{-3} \mathrm{M}$ で, SPRP の場合 $1.0 \times$ $10^{-2} \mathrm{M}$ でそれぞれ $98 \mathrm{wt} \%$ に達することが明らかであ る。DSHP が CST の生成を促進する効果がもっとも小 さく, $1.0 \times 10^{-2} \mathrm{M}$ で $28 \mathrm{wt} \%$ の CST が生成した。図 中に 1 で示した・は添加物を加えないで半回分式反応を 行った場合の FRcsh-sp である。

反応温度と FRcsh-sp 拈よび FRcst との関係を図-2 に示す。反応は添加物濃度 $1.0 \times 10^{-3} \mathrm{M}$ で行った。 1 は 添加物を加えない場合の FRcsh-sp の温度依存性であ

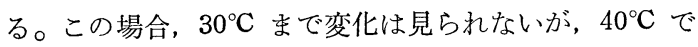
FRcsh-sp がやや低下する。STPP を加えた場合, 15〜 $30^{\circ} \mathrm{C}$ の間では生成物のほとんどすべてが CSH-sp であ るが，これより低い温度では FRcsh-sp は徐々に低下 し， $0^{\circ} \mathrm{C}$ では CSH-sp の生成は認められなかった。この 低温域での FRcsh-sp の低下が CST の生成に起因して いることは, 図-2 の温度と FRcst との関係から明らか である。 $30^{\circ} \mathrm{C}$ より高い温度でも FRcsh-sp の值は低下

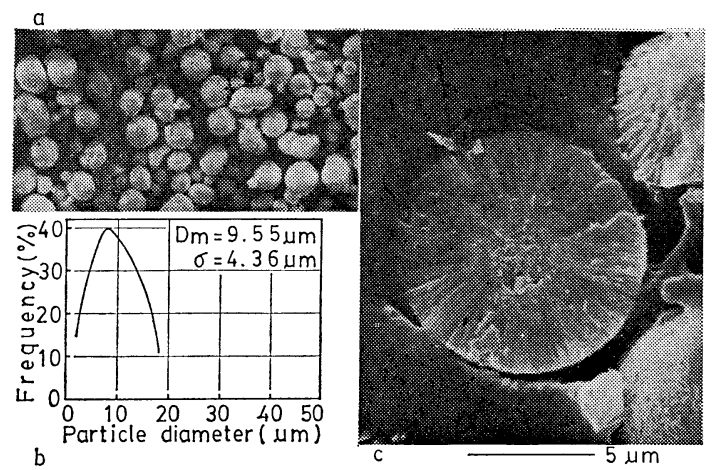

Fig. 3. The CSH-sp obtained from the first reaction

a : The external view of the CSH-sp

b: The particle size distribution

c: The cross section of the CSH-sp

Table 1. X-ray analysis of the CSH-sp

\begin{tabular}{lcrrr}
\hline \multirow{2}{*}{ hkl } & \multirow{3}{*}{ d $_{\text {obs. }}(\AA)$} & \multicolumn{3}{c}{$\mathrm{I} / \mathrm{I}_{0}$ (obs. $)$} \\
\cline { 3 - 5 } & & $\mathrm{A}$ & $\mathrm{B}$ & $\mathrm{C}$ \\
\hline 200 & 5.332 & 15 & 20 & 100 \\
212 & 3.152 & 100 & 100 & 70 \\
122 & 2.618 & 60 & 50 & 20 \\
\hline
\end{tabular}

A : The CSH-sp not ground

$\mathrm{B}$ : The $\mathrm{CSH}$-sp finely ground

C: The CSH-sp divided to plates or colums (the $\mathrm{CSH}-\mathrm{sp}$ is made up of these crystals)

するが，これは亜硫酸カルシウム半水和物の無定形結晶 集合体の生成に 起因するものである。SPRP の場合も $\mathrm{STPP}$ の場合とほぼ同様な傾向にあり， $5 \sim 30^{\circ} \mathrm{C}$ の範囲 で生成物の ほとんどすべてが CSH-sp となり，その 前後で FRcsh-sp は低下した。DSHP についても， STPP 执よび SPRP の場合と同様な傾向にあることが 図-2 から明らかである。図-1 および図-2 に示した結果 より，CSH-sp および CST の生成を促進する効果は STPP がもっとも大きく, 次が SPRP, 次が DSHP で あることが明らかである。

$1.0 \times 10^{-3} \mathrm{M}$ の SPRP を含も水酸化カルシウム懸濁 液 $(0.4 \mathrm{M})$ を用いた半回分式反応 $\left(5^{\circ} \mathrm{C}\right)$ により生成し たCSH-sp の外観 (a)，粒度分布（b）抌よび断面 (c) を図-3 に示す。平均粒径は定方向径 (Feret 径, $\mathrm{n}=300)$ を測定し, 統計処理により個数平均径として算 出した。添加物を加えないで，他の条件は上記反応と同 一にして半回分式反応を行った場合, その生成物の一部 は CSH-sp として生成する（図-1）。この場合の CSH- 
$\mathrm{sp}$ の平均粒径が $5.61 \mu \mathrm{m}^{14)}$ であるのに 対して, SPRP を $1.0 \times 10^{-3} \mathrm{M}$ 含む水酸化カルシウム䀣濁液を用いた 場合のそれは $9.55 \mu \mathrm{m}$ であり, SPRP の存在が $\mathrm{CSH}$ sp の粒径を増大させていることが明らかである。cに 示した断面は CSH-sp をエポキシ樹脂に練り込み，樹 脂硬化後, ガラスナイフで樹脂ごと薄切して得た。 CSH-sp が中心から放射状に広がった多数の結晶からな っていることがよく観察される。

$\mathrm{CSH}-\mathrm{sp}$ の粉末 X線回折の結果の一部を表-1 に示す。 $\mathrm{A}$ は非破壊の CSH-sp， B は微粉粋した CSH-sp，Cは CSH-sp が解れる程度にエタノール中で粉粋し，そのま まガラス 製支持板上に 薄く 展開したものの，（200）, （212）执よび（122）の回折強度である。回折強度に関 して、AとBとの間にはほとんど差異が認められない。 これに対して，Cに拈いては（200）の強度が増大し， （212）扣よび（122）の強度が減少している。これら の結果から，(212）および (122) は成長面, すなわち CSH-sp の表面を形成する面であると，また（200）は CSH-sp の内部に存在する面であると推察される。

\section{2 多層構造を有する CSH-sp}

SPRP $1.0 \times 10^{-3} \mathrm{M}$ を反応系に共存させることにより 生成した CSH-sp を含む懸濁液の半量 $(500 \mathrm{ml})$ をと り,これに水酸化カルシウム $0.4 \mathrm{~mol}, \mathrm{SPRP} 1.0 \times$ $10^{-3} \mathrm{~mol}$, イオン交換水を加え, 全容を $1000 \mathrm{ml}$ にし, 再び二酸化硫黄を供給して 半回分式反応 $\left(5^{\circ} \mathrm{C}\right)$ を行っ た。この反応により生成した 2 重構造を有する CSH-sp の電子顕微鏡写真および粒度分布を図-4 に示す。平均 粒径が 1 回目の反応で生成した CSH-sp に比べて約 1.5 倍になり, 粒度分布の幅も増大した。cは 2 重構造 を有する CSH-sp の断面である。1 層目と 2 層目の境 界がはっきりと観察される。また，外側の層を構成して いる板状，柱状，あるいは針状の結晶は内側の層の中心 方向に配向していることがよく観察される。図-5に2 層目のみを破壊した 2 重構造を有する CSH-sp の電子 顕微鏡写真を示す。放射状構造をなす断面およびモザイ ク模様をなす表面が観察される。前述の方法で半回分式 反応を 4 回繰り返すことにより，生成した 4 層構造を有 する CSH-sp を図-6 に示す。平均粒径が $19.5 \mu \mathrm{m}$ であ り，1回目の反応から得られた CSH-sp の平均粒径の 約 2 倍になっていることがわかる。

層の厚さは場所により多少異なるが，いずれもおよそ $5 \mu \mathrm{m}$ である。層の厚さは, 反応物濃度, 反応温度, 二酸 化硫黄供給速度などを変化させることにより，広い範囲 で調節することが可能であると考えられる。1層構造お よび多層構造を有する CSH-sp の化学組成を表-2 に示

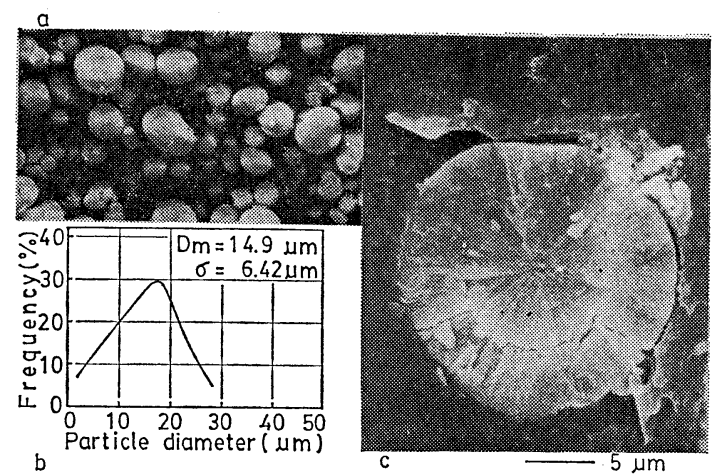

Fig. 4. The CSH-sp obtained from the second reaction

a: The external view of the CSH-sp

b: The particle size distribution c : The cross section of the CSH-sp

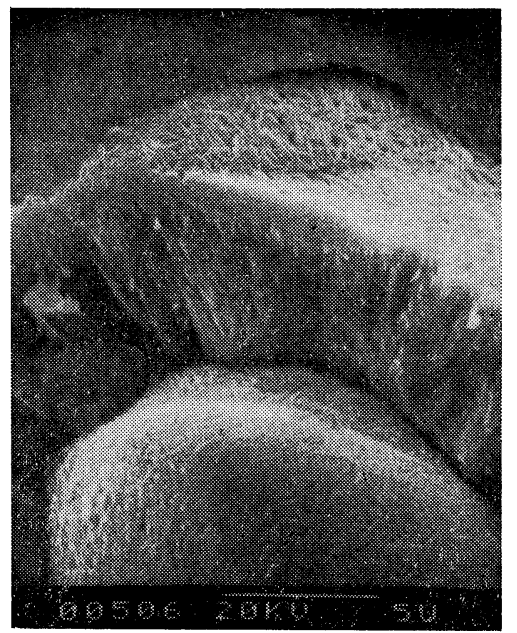

Fig. 5. The CSH-sp (double layer structure) which was destroyed partially

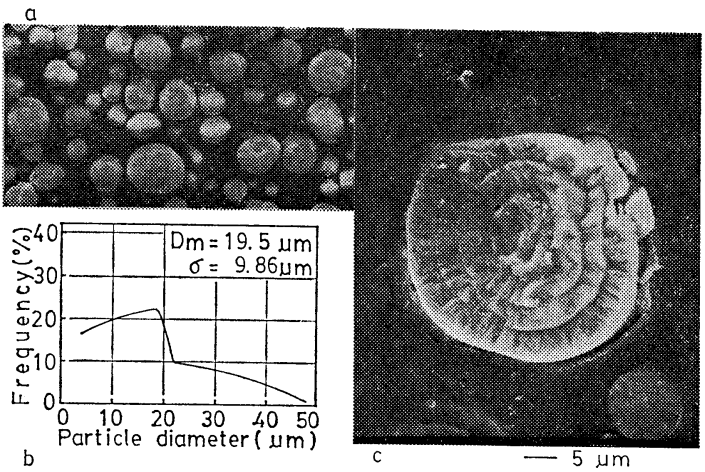

Fig. 6. The CSH-sp obtained from the fourth reaction

a: The external view of the CSH-sp

$\mathrm{b}$ : The particle size distribution c: The cross section of the CSH-sp 
Table 2. Chemical composition of the CSH-sp obtained by the semibatchwise reactions

\begin{tabular}{ccccc}
\hline & \multicolumn{4}{c}{ Chemical composition } \\
\cline { 2 - 5 } & $\mathrm{CaO}$ & $\mathrm{SO}_{2}$ & $\mathrm{CaSO}_{4}$ & $\mathrm{Ca}(\mathrm{OH})_{2}(\mathrm{wt} \%)$ \\
\cline { 2 - 5 } 1 & 42.4 & 46.3 & 1.08 & 3.42 \\
2 & 42.1 & 46.8 & 1.10 & 2.29 \\
3 & 41.9 & 47.2 & 1.07 & 1.68 \\
4 & 41.8 & 47.3 & 1.08 & 1.47 \\
\hline Calcd. & 43.4 & 49.6 & & \\
\hline
\end{tabular}

す。 $1,2,3,4$ は先れ艺れ 1 回目， 2 回目，3回目，4回 目の反応で生成した CSH-sp の化学組成である。回が 増すにつれて, $\mathrm{Ca}(\mathrm{OH})_{2}$ の量が減少している。このこ とは, $\mathrm{Ca}(\mathrm{OH})_{2}$ が CSH-sp の中心付近に多く存在して いることを意味する。CSH-sp は，まず初めに多数の巠 硫酸カルシウム半水和物の結晶核が反応系の狭い領域に 発生し，先和らがそれぞれ放射状に発達して形成された と考兄られる。この時に, 同じ反応系偟存在する水酸化 カルシウムの小さい結晶が, CSH-sp の中心付近に捕兄 られることは十分に考兄られる。この推察は 1 層から 4 層までの構造を有する $\mathrm{CSH}-\mathrm{sp}$ 中の $\mathrm{Ca}(\mathrm{OH})_{2}$ 量の分析 值から得られた結論とよく符号する。このことは, 出発 物質の一つである水酸化カルシウム懸濁液に水酸化カル シウム拉よび二酸化硫黄と反応しない他の化学種の固相 を加えて技き，これを反応供すことにより，この固相 を少量ではあるが，水酸化カルシウムと共に包み込むこ と（マイクロカプセル化）ができる可能性を示唆するも のであり興味深い。1から4のいずれについても， 約 $1.1 \mathrm{wt} \%$ の $\mathrm{CaSO}_{4}$ の存在が認められるが, これらは, 亜硫酸カルシウム半水和物の一部が酸化された結果, 生 成したものと考觉られる。

$\mathrm{CSH}$-sp (SPRP $1.0 \times 10^{-3} \mathrm{M}$ になるように半回分 式反応系に添加して， $5^{\circ} \mathrm{C}$ で合成した）の表面呿よび断 面について, リン元素の微量分析を行った。分析は 2.6 に記したエネルギー分散形X線分析装置を用いて行っ た。試料支持はナイロンメッシュで行った。CSH-spの 断面の分析は, CSH-sp をエポンに包埋後, 約 $1 \mu \mathrm{m}$ の 厚さにガラスナイフで薄切したものを用いて行った。ま た，表面の分析はふりかけ法で行った。表面叔よび断面 の測定結果に差異が認められなかったので, 断面の結果 （面分析）だけを図-7 に示す。ウィンドウ幅内のカウン 卜数の積分值は 247241 カウントであった。図中にSで 示したピークは $\mathrm{S}-\mathrm{K}_{\alpha}$ 線 $(2.31 \mathrm{keV})$ および $\mathrm{S}-\mathrm{K}_{\beta}$ 線 $(2.47 \mathrm{keV})$ が重なったものである。また，Ca で示し

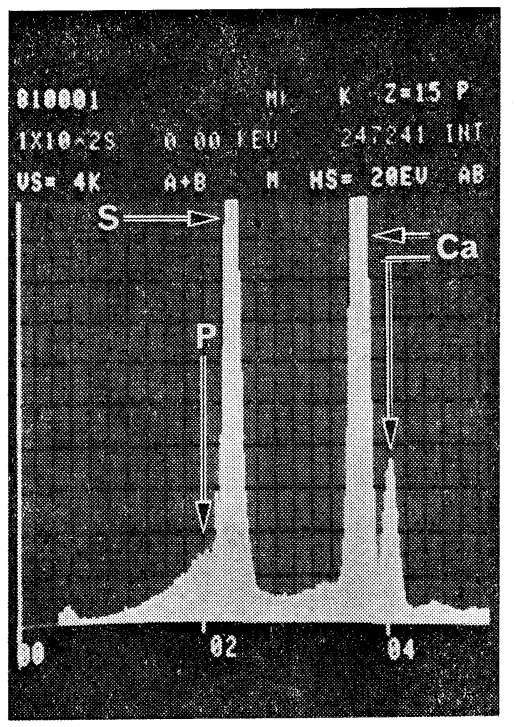

Fig. 7. Energy dispersive X-ray analysis of the cross section of CSH-sp (obtained from the first reaction)

た 2 本のピークは低ェネルギー側から $\mathrm{Ca}-\mathrm{K}_{\alpha}$ 線（3.69 $\mathrm{keV}), \mathrm{Ca}-\mathrm{K}_{\beta}$ 線 $(4.01 \mathrm{keV})$ である。 $\mathrm{S}$ のピークの低 エネルギー側の肩の部分に小さなピーク（図中に $\mathrm{P} て ゙$ 示 した）が認められるが，これは $\mathrm{P}-\mathrm{K}_{\alpha}$ 線 $(2.01 \mathrm{keV})$ である。CSH-sp の表面の測定結果にもまったく同じ位 置に $\mathrm{P}-\mathrm{K}_{\alpha}$ 線の小さいピークが認められることから， CSH-sp の表面拈よび断面 (CSH-sp を構成している板 状，柱状，あるいは針状の結晶の表面）に、リン原子が 微細なピロリン酸カルシウム（五水和物）結晶 ${ }^{15)}$ などの 形で, 吸着, あるいは固溶して存在していることが推察 される。また，リン酸基が錯イオンを形成して， CSH一 $\mathrm{sp}$ の表面拉よび断面に吸着していることも考觉られ る ${ }^{16)}$ 。これらの吸着および固溶がなんらかの形で CSH一 $\mathrm{sp}$ の生成を促進する働きに関与しているのかも知れな い。STPP の $5.0 \times 10^{-4} \mathrm{M}$ の添加, DSHP の $5.0 \times$ $10^{-3} \mathrm{M}$ の添加によって生成する CSH-sp そついても $\mathrm{SPRP}$ を添加した場合と同樣な $\mathrm{P}-\mathrm{K}_{\alpha}$ 線のピークが認 められた。リン酸基の添加により， CSH-sp の生成が促 進される理由として，上述の結晶表面への吸着掞よび固 溶現象がまずあげられるが，この外に，リン酸基がカル シウムイオンと共に錯体（結晶析出による自由エネルギ 一変化を効果的に減少させる働きがある）を形成し榡濁 液中に存在し，これが亜硫酸カルシウム半水和物の核形 成执よび結晶成長過程に影響を与えて，その結果として $\mathrm{CSH}-\mathrm{sp}$ の生成が促進される可能性も考兄られる ${ }^{17,18) 。 ~}$ 


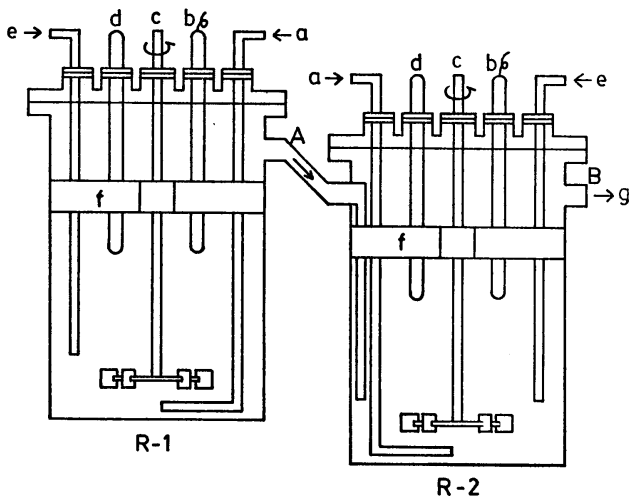

Fig. 8. Apparatus for the continuous reaction a : $\mathrm{SO}_{2}$ gas $(50 \mathrm{vol} \%)$ $\mathrm{b}: \mathrm{pH}$ meter c: Turbine type agitator $\mathrm{d}$ : Thermometer e : $\mathrm{Ca}(\mathrm{OH})_{2}$ suspn. $(0.4 \mathrm{M})$ f : Buffle plate $\mathrm{g}:$ Reaction product
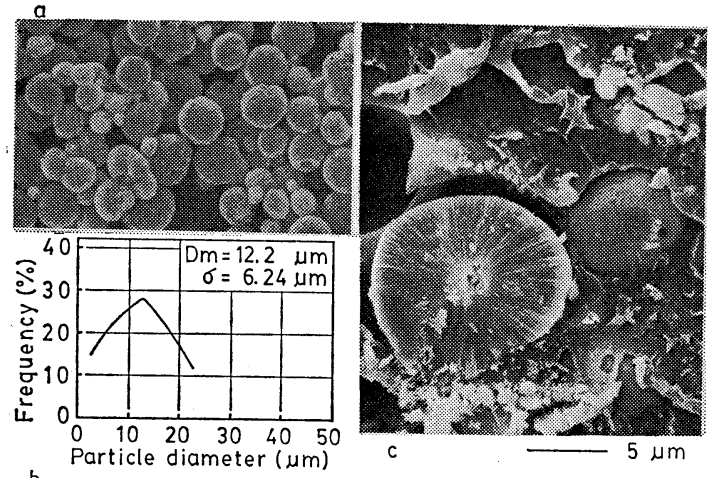

Fig. 9. The CSH-sp obtained by the continuous operation (the sample was withdrawn at the position of $A$ )

a: The external view of the CSH-sp

$\mathrm{b}$ : The particle size distribution

c: The cross section of the CSH-sp

\section{3 連続式不均一系反応による CSH-sp の合成}

図-8 と示した装置を用いて，連続式反応を行い CSH-sp の合成を試みた。 R-1， R-2 ともに反応温度 $5^{\circ} \mathrm{C}$ で行った。反応に 供した 水酸化カルシウム䀣濁液 （R-1 打よび R-2 飞供給した）には，あらかじめ SPRP を $1.0 \times 10^{-3} \mathrm{M}$ の濃度になるように添加した。 他の条件は 2.2 特よび 2.3 に記した通りである。R-1 の生成眯濁液流出口Aで採取した $\mathrm{CSH}-\mathrm{sp}$ を図-9 亿示 す。SPRP を添加せずに連続式反応 $\left(5^{\circ} \mathrm{C}\right)$ を行った場 合, 生成物の一部が CSH-sp として得られるが，その球 形度は半回分式反応（無添加物）の場合に比べてかなり 低下する ${ }^{19)}$ 。図-9 の a から明らかなように, SPRPを添

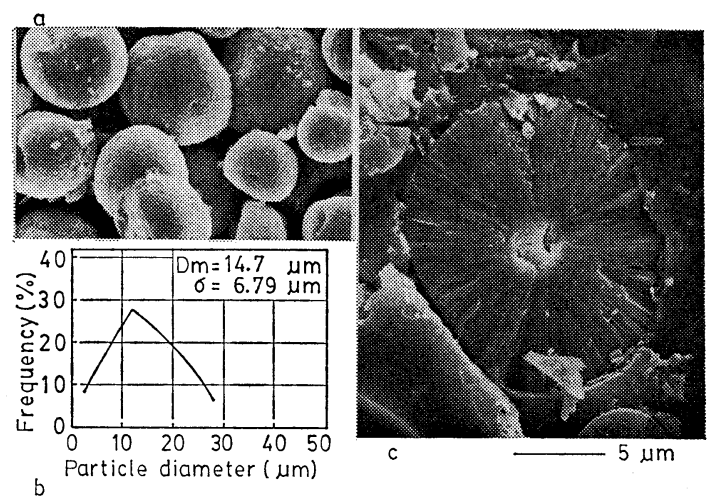

Fig. 10. The CSH-sp obtained by the continuous operation (the sample was withdrawn at the position of $B$ )

a: The external view of the CSH-sp

$\mathrm{b}$ : The partical size distribution

c: The cross section of the CSH-sp

加して行った連続式反応によって生成した CSH-sp の 球形度は半回分式反応汒上った CSH-sp（図-3）のそれ と同等である。しかも，生成物のほとんどすべてが CSH-sp として得られる。平均粒径 (図-9-b) は半回分 式反応によった CSH-sp に比べて增大しているが，こ れは核発生時および結晶成長時の 過飽和度の 相違, ま た，反応液の $\mathrm{pH}$ の “むら”程度の相違によるものと考 えられる ${ }^{19)}$ 。c は断面の電子顕微鏡写真である。半回分 式反応によった場合と同様, きわめて高密度に板状, 柱 状拉よび針状の結晶が中心から放射状に配列している様 子が観察される。

R-2 の生成眯濁液流出口 Bで採取した CSH-sp を図10 に示す。平均粒径が $14.7 \mu \mathrm{m}$ であり，R-1 出口で採 取した CSH-sp のそれより $2.5 \mu \mathrm{m}$ 大きくなっている。 これは R-1 から R-2 に移動した CSH-sp が R-2 で成 長したことを意味する。cは断面の写真である。放射状 に中心から表面まで, 連続して真っ直ぐに伸びた多数の 結晶が観察され，半回分式反応を 2 回絽り返して行った 場合に得られた CSH-sp に見られた 2 層構造は認めら れない。半回分式反応の場合, 2 回目の反応の開始時に 無数の亜硫酸カルシウム半水和物の結晶核が，1回目の 反応で生成した CSH-sp の表面に発生し，それらが，再 び放射状に 発達して， 2 層構造をとる CSH-sp を形成 したものと考兄られる。これに対して，R-2 内での反応 (回分式反応の 2 回目の反応に相当する) では， R-1 か ら移動してきた CSH-sp の表面に 新しい核が 発生する ことなく，CSH-sp を構成している結晶がそのまま連続 して成長して，CSH-sp の粒径を増大させたものと考兄 
Table 3. Chemical composition of the CSH-sp obtained by the continuous reaction

\begin{tabular}{ccccc}
\hline & \multicolumn{4}{c}{ Chemical composition } \\
\cline { 2 - 5 } $\mathrm{A}$ & $\mathrm{CaO}$ & $\mathrm{SO}_{2}$ & $\mathrm{CaSO}_{4}$ & $\mathrm{Ca}(\mathrm{OH})_{2}($ wt $\%)$ \\
\cline { 2 - 5 } $\mathrm{B}$ & 42.6 & 48.2 & 1.27 & 0.12 \\
$\mathrm{~B}$ & 42.6 & 48.3 & 1.32 & 0.10 \\
\hline Calcd. & 43.4 & 49.6 & &
\end{tabular}

られる。この相違が生じる理由として次のことが考えら れる。半回分式反応の 2 回目では, 反応液の $\mathrm{pH}$ は大量 の水酸化カルシウムの存在により 12.6 となる。ここに 二酸化硫黄が供給されると, 溶液中の亜硫酸カルシウム の過飽和度は急激に上昇し，瞬時のうちに多数の核が発 生する 条件が 調い, 次に 2 層構造形成の 基礎になる核 が，CSH-sp の表面に析出することになる。これに対し て, 連続式反応では $\mathrm{R}-1$ および $\mathrm{R}-2$ 内の反応液の $\mathrm{pH}$ が $7.0 〜 8.0$ に常に保たれて抢り，極端に高い過飽和状 態になることはない。そのため，大量の新しい核が発生 することなく，既存の結晶がそのまま連続して成長し， 層状構造をとらない CSH-sp が生成したと考兄られる。 SPRP を $1.0 \times 10^{-3} \mathrm{M}$ の濃度になるように水酸化力 ルシウム懸濁液に添加して行った連続式反応から得られ た CSH-spの化学組成を表-3に示す。Aは R-1 の流出 ロで， B R-2 の流出口で採取した CSH-sp である。 半回分式反応から得られたものに比べて, $\mathrm{CaSO}_{4}$ がわず かに増加し, $\mathrm{Ca}(\mathrm{OH})_{2}$ が大幅に減少している。連続式 反応では, 反応液の $\mathrm{pH}$ を 7.0 〜 8.0 に保っているた め, 二酸化硫黄を含む気泡の近傍の 局部的な酸性の程 度が，半回分式反応（反応時間の 90 数\% は $\mathrm{pH} 12.6$ の状態にある）のそれに比べて強くなる。このため, 亜 硫酸カルシウムの酸化がいくらか促進され, $\mathrm{CaSO}_{4}$ が増 加したと考えられる。また, 連続式反応では反応系に存 在する水酸化カルシウムが少なく, CSH-sp の中心付近 に取り达まれる量が少ないため, $\mathrm{Ca}(\mathrm{OH})_{2}$ が減少した
と考えられる。

$\mathrm{CSH}-\mathrm{sp}$ の粒度制御は添加物濃度, 反応温度などを変 えることによっても可能であると考えられるが，多層構 造を有する CSH-sp であれば半回分式反応を繰り返す ことにより，多層構造をとらない $\mathrm{CSH}-\mathrm{sp}$ であれば連 続式反応に打いて, その反応器の数を増減することによ り,さらに大幅な粒度の制御が 可能になると考えられ る。

\section{参考文献}

1）水渡英二：材料，24，588（1975）

2) 平田好顕：日本接着協会誌，11，67（1975）

3) T. Morimoto, T. Kadota, H. Yanazawa, S. Kittaka : Bull.Chem.Soc.Jpn., 53, 26 (1981)

4) 田久敏行：プロメテウス， 5，54 (1981)

5) T. Sugimoto, E. Matijević : J. Colloid Interface Sci., 74, 227 (1980)

6) T. Sugimoto, T. Yamaguchi : J. Cryst. Growth, 34, 253 (1976)

7) C. W. Bunn 著, 笹田義夫訳 : “化学結晶学”, p. 52 , 培風館 (1970)

8) E. M. Macchi : J. Polym. Sci., Part A-1, 10, 45 (1972)

9) J.F. Jackson, T.S.Hsu, J. W. Brasch : $J$. Polym. Sci., Part B, 10, 207 (1972)

10) R. C. Ewing : Science, 184, 561 (1974)

11) P. J. Blau, H. J. Axon, J. I. Goldstein : $J$. Geophys. Res., 78, 363 (1973)

12) V.Satava, B. Zbuzek: Zem.-Kalk-Gips, 26, 518 (1973)

13) K. Makino, T. Nakagawa, K. Kobayashi, M. Shinohara: J. Appl. Phys., 49, 1834 (1978)

14）松野昂士, 小石真純：色材, 55, 136 (1982)

15）青木繁樹, 今井 聰, 荒井康夫: Gypsum Lime, 169, 2 (1980)

16）青木繁樹，荒井康夫：日化，1974，60

17) E. Matijević : J. Colloid Interface Sci., 58, 374 (1977)

18) B. Tomazic, G. H. Nancollas : J. Colloid Interface Sci., 75, 149 (1980)

19）松野昂士，小石真純：色材, 53，319（1980） 


\title{
The Effects of Phosphate Ions on the Calcium Sulfite Hydrate Formation and Multilayered-Structure of Spherulite
}

\author{
Takashi Matsuno* and Masumi Korshi** \\ * School of Medicine, Kitasato University ; 1-15-1 Kitasato, Sagamihara-shi, \\ Kanagawa-ken, 228, Japan \\ ** Faculty of Pharmaceutical Sciences, Science University of Tokyo ; 12 Ichigaya, \\ Funagawaramachi, Shinjuku-ku, Tokyo, 162, Japan
}

\begin{abstract}
The spherulites of calcium sulfite hemihydrate and the crystals of calcium sulfite tetrahydrate were produced at low temperatures when a small amount of sodium triphosphate, sodium pyrophosphate or disodium hydrogenphosphate was added to the semibatchwise heterogeneous reaction system of calcium hydroxide and sulfur dioxide. The order of the magnitude of the function of additives to accelerate the formation of spherulite and tetrahydrate crystal was as follows: sodium triphosphate $>$ sodium pyrophosphate $>$ disodium hydrogenphosphate. The spherulites which have multilayered-structure were produced when a small amount of phosphate described above was added to the system by repetition of the semibatchwise heterogeneous reaction $\left(5^{\circ} \mathrm{C}\right)$. The spherulites were also synthesized in good yields from sulfur dioxide and milk of lime containing a small amount of above-mentioned phosphate by continuous heterogeneous reaction at $5{ }^{\circ} \mathrm{C}$.
\end{abstract}

色材協会誌 Vol. 56, No. 12 予告

報文

オルガノゾルに関する研究 [I]オルガノゾルに括ける樹脂粒子溶媒間相互作用力と

分散安定性との関連…………………….......................関西ペイント(株) 田中 正一, 他

$\mathrm{X}$ 線光電子スペクトル (XPES) によるアルコールで処理された

シリカゲル及び $\mathrm{CVD}-\mathrm{SiO}_{2}$ 薄膜表面付着基の同定…………………宇都宮大学 宇津木 弘, 他

顔料の触媒活性 ( IV ) 顔料の酸性点に対するアルカリ金属の効果……(株)資生堂研究所 福井 寛, 他

顔料講座 (12 講) 最終回

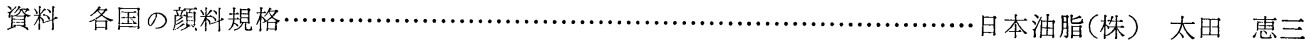

色材サロン

ベんがらのふるさと吹屋を訪ねて………….........................阪工業技術試験所 信岡 聰一郎 